Philip Hartog, the first Vice-Chancellor, at a meeting of the University Court last November. Chief among these principles is the residential organisation combined with a tutorial system. At Dacca three halls have been established on the lines, so far as possible, of the Oxford and Cambridge colleges, and in each of them have been started literary and debating societies, athletic societies, and social service leagues. Later a University Union was created. Whilst these halls and societies form valuable schools for character training and citizenship, the most important new element on the teaching side is the tutorial work, with the corresponding practical work supervised by the teachers in the laboratories. Much attention has been devoted to the physical welfare of students, and the executive council has decided that physical exercises ought to be compulsory for all students who are not medically unfit. There has been a notable increase in the number of Mohammedan students, from I70 out of a total of 1075 in 192I, to 353 out of a total of 1487 in 1925 . The institution of the Dacca Board of Secondary and Intermediate Education, in accordance with the recommendations of the Calcutta University Commission, has not, so far, led to as much improvement as was expected. Experience has shown the need of a practical test at the intermediate examinations in science, but its introduction has been postponed sine die. Sir Philip Hartog remarks that the Board should be so constituted that the financial stability and progress of the educational institutions with which the members are connected would not depend on the passing of any particular number of candidates.

THE United States Commissioner of Education's report for $1924-25$ concludes a tale of varied and multitudinous activities with the statement that the Commissioner travelled 43,444 miles and made ${ }_{57}$ addresses before audiences aggregating 87,4 Io. Specially impressive is the list of publications of the Bureau of Education, comprising, in addition to fiftyeight bulletins and the periodical School Life, numerous special series of leaflets relating to city schools, commercial education, health education, home economics, home education, industrial education, and other matters, library leaflets, reading courses, rural school leaflets, etc. The Commissioner devotes a large share of his attention to rural education, and undertook during the year in this connexion a new type of activity, namely, co-operation on an extensive scale with selected educational organisations for the coordination and conduct of educational research studies. In addition, he caused a large number of special studies to be made of various aspects of the work of rural schools. His Home Education Department conducts reading courses with the cooperation of State universities or the State library commission or State normal college. The scope of the work seems to be very much on the lines of that of the National Home Reading Union in Great Britain; I522 readers were enrolled during the year, and the number of readers who have at some time enrolled exceeds 18,500 . In view of the notoriety of Tennessee's legislation on the subject of the teaching of the doctrine of evolution, it is interesting to note that a report of a survey by the Bureau's Division of Higher Education directed attention to the low proportion of the college population in that State, the inadequate financial support of the colleges, the lack of co-operation between colleges conducted under the auspices of the same Church denomination, low rates of tuition, inadequate preparation of the faculties of some institutions, and the small attendance of students from counties difficult of access.

\section{Contemporary Birthdays.}

May 8, r858. Sir Bertram C. A. Windle, F.R.S. May 9, 1877. Sir James C. Irvine, F.R.S. May I3, I854. Dr. Marie Yves Delage. May 13, 1857. Sir Ronald Ross, K.C.B., F.R.S May I3, r85r. Sir Horace Darwin, K.B.E., F.R.S.

Sir Bertram Windle, professor of anthropology in St. Michael's College, University of Toronto, was educated at Repton and the University of Dublin. Before his activities were transferred to Canada, he was professor of anatomy and anthropology in the University of Birmingham; afterwards president of University College, Cork, and whilst resident in Ireland, was much concerned with schemes of Irish education. Apart from scientific memoirs, Sir Bertram is the author of many informing books in general archæology and anthropology, including "The Romans in Britain" (I923).

Sir JAmes IRvine was educated at Allan Glen's School, Glasgow, and the Universities of St. Andrews and Leipzic. Formerly professor of chemistry and Director of the Research Laboratory at St. Andrews, he is now Principal and Vice-Chancellor. $\mathrm{He}$ is an authority on the constitution and chemistry of sugars. Continuing the researches of Emil Fischer, and in collaboration with the late Prof. Purdie, he evolved new processes of investigation relating to these important natural products. Sir James was awarded the Royal Society's Davy medal last year in recognition of his work.

Dr. Yves DelaGe, professor of zoology in the Faculté des Sciences, Paris, and director of the Marine Biological Laboratory at Roscoff, was born at Avignon. He is an Officer of the Legion of Honour and a member of the Paris Academy of Sciences. Leaving teaching work at Caen (1886) he succeeded the late Prof. Milne Edwards in his professorial chair. Dr. Delage is the author of numerous monographs in experimental and general biology.

Sir Ronald Ross, director of the Ross Institute and Hospital for Tropical Diseases, Putney Heath, received his medical training at St. Bartholomew's Hospital. Qualifying in I88I for the Indian Medical Service, he served until $\mathrm{x} 899$. It was a period fruitful in biological achievement. Following up some suggestions offered by the late Sir Patrick Manson, investigations were begun by Ross in 1895 , in India, with the view of determining the life-history of the parasite of malaria (discovered by Laveran) and the transmission of infection. Ross was able to indicate the cycle of changes of the malarial organism in the tissues of a mosquito (Anopheles) which had been fed on the blood of a malarial patient. His work is the basis of modern methods for the prevention of malaria. Sir Ronald is a Nobel laureate, and a Royal medallist of the Royal Society.

Sir HoRACE, DARWIN may be, not inaptly, termed the apostle of methods of instrumental precision. Receiving his early training at Messrs. Eastons and Anderson, Erith, Kent, he graduated at Trinity College, Cambridge. $\mathrm{He}$ is chairman of the Cambridge Scientific Instrument Company, Ltd. Sir Horace gave the first Wilbur Wright Memorial Lecture before the Aeronautical Society in $19 \mathrm{I}_{3}$ on "Scientific Instruments: their Design and Use in Aeronautics." It was prefaced by some interesting considerations respecting birds, the flight of insects, and 'winged plants.' Sir Horace was a member (I9I5 onwards) of the Munitions Inventions Panel. 